\title{
Industrialization, Servicification And Environmental Kuznets Curve: Non-Linear Panel Regression Analysis
}

Fatma Taşdemir ( $\square$ ftasdemir@sinop.edu.tr)

Sinop University https://orcid.org/0000-0001-8706-7942

\section{Research Article}

Keywords: Environmental Kuznets Curve, Industrialization, Servicification, Panel Smooth Transition Regression

Posted Date: June 15th, 2021

DOl: https://doi.org/10.21203/rs.3.rs-291941/v1

License: (c) (1) This work is licensed under a Creative Commons Attribution 4.0 International License. Read Full License

Version of Record: A version of this preprint was published at Environmental Science and Pollution Research on August 27th, 2021. See the published version at https://doi.org/10.1007/s11356-021-160129. 
8 INDUSTRIALIZATION, SERVICIFICATION AND ENVIRONMENTAL KUZNETS 9 CURVE: NON-LINEAR PANEL REGRESSION ANALYSIS

Key words: Environmental Kuznets Curve, Industrialization, Servicification, Panel Smooth Transition Regression

JEL Classification: L60, L80, Q50, Q56

\author{
JEL Classification: L60, L80, Q50, Q56
}

Fatma Taşdemir

Sinop University, Sinop, Turkey

E-mail: ftasdemir@sinop.edu.tr

\begin{abstract}
This paper investigates whether the impact of income on $\mathrm{CO}_{2}$ emissions is invariant to endogenously estimated threshold levels for the economic structure (ES) represented by value added in manufacturing, industry and services sector shares in GDP for a panel of 54 economies over the 1971-2017 period. Our panel smooth transition regression estimation results strongly suggest that the sensitivity of $\mathrm{CO}_{2}$ emissions to income is substantially much higher in countries with higher manufacturing and industry sector shares whilst it is much lower in servicified economies. Given the argument that manufacturing is the engine of growth, this finding may not necessarily downgrade the crucial importance of an industrial policy which places the manufacturing at the core. The empirical findings in this paper suggest that countries may better to design and implement a strategic and systematic industrial policy which promote the use of emission reduction technologies and encourage manufacturing and industrial sectors with lower carbon emissions.

ABSTRACT
\end{abstract}




\section{Introduction}

The conventional environmental Kuznets curve (EKC) maintains that $\mathrm{CO}_{2}$ emission increases with income and after a turning point, higher income leads to a deceleration. According to the EKC, during the earlier stage of development, the content of economic activities may include substantial deleterious impacts on environment because the economies are "too poor to be green" (Martinez-Alier, 1995). After a certain income level, countries aim to grow by considering the impacts of economic activities on environment and thus begin to follow a "green growth" path. Therefore, environmental economists often maintain that income is both the cause and cure of degradation as suggested by the inverted-U shaped EKC. In this context, investigating the driving forces behind the inverted- $U$ shaped EKC is crucially important research topic in environmental economics.

The seminal study by Grossman and Krueger (1991) suggests the validity of inverted-U shaped relation between income and emissions based on the scale, composition and technique effects. The scale effect implies the deterioration in environmental quality with the increase in income. The composition and technique effects, respectively, denote the improvement in environmental quality mainly by the movement of economic structure from polluted industrial to greener services sector and employment of environment-friendly technologies. In this context, Grossman and Krueger (1991) maintains that the upward sloping part of EKC may be explained with the scale effect while the downward sloping part of EKC may be illustrated with the composition and technique effects. Following Grossman and Krueger (1991), the bulk of the literature often investigates the validity of inverted-U shaped EKC relation by using different income and environmental degradation measures. Shahbaz and Sinha (2019) provides a recent literature survey on EKC. The conventional EKC maintains that income, the aggregated measure of economic activities, intimately explains the evolution of environmental deceleration and improvement. However, the recent literature also suggests that economic structure is 
crucially important in explaining the impacts of income on environmental degradation and thus the ignorance of this issue may lead to misleading conclusions on the validity of EKC.

The recent literature including Kearsley and Riddel (2010), Marsiglio et al. (2016), Neve and Hamaide (2017) and Shahbaz and Sinha (2019) notes that economic structure, often represented by manufacturing share in GDP, is one of the most important determinants of $\mathrm{CO}_{2}$ emissions. Chen et al. (2020) reports that almost half of the $\mathrm{CO}_{2}$ emissions is related with economic activities in the industrial sector including mining and quarrying, manufacturing, electricity, gas and water supply and construction. The empirical findings by Friedl and Getzner (2003) and Mulder and de Groot (2012) suggest that the prevalence of services sector leads to improvement in environmental quality. Therefore, it may be plausible to suggest that $\mathrm{CO}_{2}$ content of economic activities differ in the countries with higher manufacturing and industrial sector shares than servicified economies represented with high services sector share. These are, indeed, consistent with the composition effect argument by Grossman and Krueger (1991). Barra and Zotti (2018), on the other hand, reports that the effects of economic structure on emissions may change depending on the net impacts of scale, composition and technique.

This study, in accord with the conventional $\mathrm{EKC}$, investigates the determinants of $\mathrm{CO}_{2}$ emissions. Considering that economic structure of countries may differ across the energyintensity and thus carbon emission levels of the main sectors, we plausibly postulate that the impacts of income on $\mathrm{CO}_{2}$ emissions may be different in economies with higher manufacturing and industry sector shares than servicified ones. The bulk of the studies investigate the EKC relation by employing the conventional panel data estimation procedures. The studies attempting to estimate the turning point of the conventional EKC often employ some quadratic or cubic regression models. These approaches, however, "may not identify other forms of nonlinearity that may exist” as suggested by Şentürk et al. (2020, p.5). Furthermore, as suggested by Richmond and Kaufmann (2006) the studies finding that the turning point of EKC that 
beyond the sample data may be misleading. Aslanidis and Iranzo (2009), in this context, notes that the employment of panel smooth transition regression (PSTR) procedure provides more flexibility than the quadratic or cubic EKC regression models. Therefore, the investigation of income-environment relation and peak/turning point of EKC based on data-driven estimation procedures like PSTR may be more reliable. The literature, however, is yet to fully investigate whether the economic structure represented by manufacturing, industry and services sectors shares in GDP provide endogenous thresholds for the impact of income on $\mathrm{CO}_{2}$ emissions. Therefore, this study mainly aims to investigate whether economic structure constitutes endogenous thresholds for the impact of income on $\mathrm{CO}_{2}$ emissions in a sample of 54 economies over the 1971-2017 period by employing PSTR procedure of Gonzalez et al. $(2005 ; 2017)$.

The results of this study suggest that the sensitivity of pollution to income changes with the endogenously determined threshold levels of economic structure. The income elasticity of pollution is substantially much higher in countries with higher manufacturing and industry shares. On the other hand, we find that the impact of income on emissions is substantially much lower in servicified economies with high services share. These findings all, indeed, may suggest the industrialization and servicification, respectively, sharpens and dampens the positive impact of income on $\mathrm{CO}_{2}$ emissions. Therefore, the empirical results in this study provide a support to the explanation of EKC with the scale effect argument by Grossman and Krueger (1991) and suggest this effect varies across the structure of economies.

The plan for the rest of this study as follows. Section 2 presents a brief review of the literature on income- $\mathrm{CO}_{2}$ relation. Section 3 introduces the empirical methodology and reports the estimation results. In this section, we postulate that economic structure is a potential endogenous thresholding (sample-splitting) variable for the impact of income on $\mathrm{CO}_{2}$ emissions. Finally, Section 4 concludes and provides some policy implications. 


\section{Literature Review}

114

There is now a large and growing literature investigating the income-environment relation by using different pollution measures. Andreoni and Levinson (2001) notes that technology employed in the production drives the income-environment relation. Millimet et al. (2003) reports that EKC appears to be valid regardless of the modelling assumptions. On the other hand, there is no universal and robust EKC according to Stern (2004). The empirical results by Akbostanci et al. (2009) and Özokcu and Özdemir (2017) indicate that an N-shaped EKC appears to be the case, respectively, for Turkey and emerging markets. The estimation results based on panel smooth transition regression by Aslanidis and Iranzo (2009) suggest that an increase in income leads to an increase in emissions, albeit the income elasticity of emission is slightly much higher for low income countries. Similarly, by finding a monotonically increasing relation between income and environmental degradation, Şentürk et al. (2020) suggests that the income elasticity of pollution differs across the income level of the economies.

The empirical findings by Torras and Boyce (1998) suggest that literacy, political rights and civil liberties are amongst the important determinants of emissions in low income countries. He and Wang (2012) finds that capital/labor ratio, trade openness and regulations are important variables in explaining the determinants of EKC in China. The cointegration based empirical results by Shahbaz et al. (2019) suggest that energy consumption, sectoral activities, foreign direct investments and urbanization are important determinants of $\mathrm{CO}_{2}$ emission in Vietnam. Barra and Zotti (2018) finds that there is a monotonically increasing relation between environment and income after controlling the impacts of trade openness, urbanization and electric consumption. The empirical findings by Lin and Li (2020) suggest that population, economic growth, urbanization and industrialization accelerate whilst the usage of electricity decelerates the $\mathrm{CO}_{2}$ emission. 
The recent literature also suggests that the impacts of economic activities on environment can be explained with the pollution haven hypothesis $(\mathrm{PHH})$ that investigates the degradation effects of trade and FDI (Cole, 2004; He and Yao, 2017; Kearsley and Riddel, 2010; Marsiglio et al. 2016; Opoku and Boachie, 2020; Usman et al. 2019). Baldwin and Lopez-Gonzalez (2015) indicates that global manufacturing has been shifted from developed to developing economies during the recent decades. In this vein, $\mathrm{PHH}$ mainly postulates that economic activities incorporating higher levels of carbon-intensive industries moves from advanced to developing economies via trade linkages and multinational corporations. Global supply chains may have also contributed the movement of dirty industries to developing economies that have relatively lax environmental standards. Fang et al. (2020) investigates the impacts of trade openness on degradation in Chinese cities. Ren et al. (2014) finds the environmental degradation impacts of trade and FDI in China. The empirical results by He and Yao (2017) and Jayanthakumaran and Liu (2012) provide a further support to the validity of pollution haven hypothesis in China. Jiang et al. (2019) reports that developed countries have been able to locate some of their energy-intensive dirty industries to developing economies because of the trade linkages and in this sense, developed countries may appear to be more successful than developing economies in reducing their emission intensive productions.

According to Dinda (2004), EKC can be explained by considering the impacts of structural change and technological progress. Savona and Ciarli (2019) provides a brief recent literature review on the structural change and environment relationships. Marsiglio et al. (2016) investigates the driving forces of EKC by constructing two sector endogenous growth model consisting of manufacture and services sectors. They remark that there may be an $\mathrm{N}$-shaped relation between income and degradation in the long-run, while the negatively sloped part of EKC, albeit temporarily, may be attributable to structural change postulation. The decomposition analysis by Akbostanc1 et al. (2018) suggests that manufacturing and 
construction sectors are crucially important drivers of $\mathrm{CO}_{2}$ emissions in Turkey. The findings by Friedl and Getzner (2003) indicate that services sector leads to a decrease in $\mathrm{CO}_{2}$ emissions. According to the shift share analysis by Henriques and Kander (2010), the transition to servicebased economic structure provides only a slight deceleration in energy intensity. The transition of economic structure from manufacturing to services is the main reason of declining energy intensity (Mulder and de Groot, 2012). The empirical findings by Du and Xie (2020) indicates that turning point of EKC is faster in deindustrialized countries than industrialized ones. Ullah et al. (2020) finds that environmental degradation impact of industrialization and environmental improvement effect of deindustrialization appear to be the case not only in the short-run but also in the long-run. The cointegration based empirical results by Dogan and Inglesi-Lotz (2020) suggest that there is a $\mathrm{U}$-shaped relation between industrial value added and $\mathrm{CO}_{2}$ emissions. The investigation of the impacts of manufacturing sector share and manufacturing trade on emissions by Suri and Chapman (1998) suggests that manufacturing exports and imports between industrialized and industrializing countries may contribute, respectively, the upward and downward sloping parts of EKC. The empirical findings by Cole (2000) are mainly consistent with the implications of EKC and PHH for a sample of developed and developing economies. Du et al. (2019) suggests that transportation sector releases substantial amount of pollution to services and construction sectors whilst expose to emission from industrial sector. The investigation of EKC in China leads to the conclusion that EKC is valid in electricity and heat production sectors while there is a monotonically increasing relation between income and emission in the manufacturing sector (Wang et al. 2017). The empirical findings by Xu and Lin (2016) suggest that the impacts of industrial sector on emissions follow an inverted-U shaped relation.

The recent literature often suggests that pollution can be explained by income which is a measure of aggregated economic activities. Akbostanc1 et al. (2018), Friedl and Getzner (2003), 
Lin and Li (2020), Mulder and de Groot (2012), Shahbaz et al. (2019) and Ullah et al. (2020) mention the importance of economic structure for the evolution of emissions. In this context, this study aims to contribute to the environmental economics literature by maintaining that the impact of income on emissions may differ across the endogenously determined threshold levels for economic structure represented with manufacturing, industry and services shares in explaining the income-pollution relation.

\section{Empirical Methodology and Results}

\subsection{Empirical Methodology}

To investigate the impact of income on $\mathrm{CO}_{2}$ emissions, we consider the following benchmark equation;

$$
\mathrm{CO}_{\text {it }}=\alpha_{0}+\alpha_{1} \mathrm{GDP}_{\mathrm{i}, \mathrm{t}-1}+\mathrm{e}_{\mathrm{it}}
$$

In (1), the subscript $\mathrm{i}$ and $\mathrm{t}$ represent, respectively, country and time, $\mathrm{CO}_{2}$ is natural logarithm of $\mathrm{CO}_{2}$ emissions per tones per capita, GDP is natural logarithm of real GDP per capita (in constant 2010 US dollars). This equation maintains that $\mathrm{CO}_{2}$ emissions may parsimoniously be explained with income. Considering the potential endogeneity of real GDP per capita for the evolution of $\mathrm{CO}_{2}$ emissions, we prefer to use lagged real GDP per capita in (1). The main data source for $\mathrm{CO}_{2}$ emissions is Joint Research Centre Emissions Database for Global Atmospheric Research. Real GDP per capita data are from World Bank, World Development Indicators.

The benchmark eq. (1) maintains that the impact of income on $\mathrm{CO}_{2}$ emissions is invariant to economic structure. Alternatively, economic structure consisting of manufacturing, industry and services sectors share in GDP may be treated as thresholding or transition variables for the impact of income on $\mathrm{CO}_{2}$ emissions. Given that there is a significant threshold, the income elasticity of $\mathrm{CO}_{2}$ emissions can be estimated by dividing the sample as high regime containing 
observations higher than the threshold and low regime including observations less than the threshold. The literature on conventional EKC often tackles the nonlinearity and/or threshold issues by employing quadratic or cubic regression models. As suggested by Şentürk et al. (2020, p.5) these approaches, however, "may not identify other forms of non-linearity that may exist". In this vein, the threshold effect of economic structure on $\mathrm{CO}_{2}$ emissions may better be investigated by employing data-driven estimation procedures. The literature, however, is yet to comprehensively investigate whether the economic structure provides endogenous thresholds for the income elasticity of $\mathrm{CO}_{2}$ emissions. In this context, we investigate this important issue empirically for a balanced panel of $54^{1}$ economies over the 1971-2017 period by employing panel smooth transition regression (PSTR) procedure of Gonzalez et al. (2005; 2017).

To investigate whether economic structure (ES) provides endogenous thresholds for the impacts of income on $\mathrm{CO}_{2}$ emissions, we consider the following equation:

$$
\mathrm{CO}_{\mathrm{it}}=\mu_{\mathrm{i}}+\beta_{0}^{\prime} \mathrm{GDP}_{\mathrm{i}, \mathrm{t}-1}+\beta_{1}^{\prime} \mathrm{GDP}_{\mathrm{i}, \mathrm{t}-1} \mathrm{~g}\left(\mathrm{ES}_{\mathrm{i}, \mathrm{t}-1} ; \gamma, \mathrm{c}\right)+\mathrm{u}_{\mathrm{it}}
$$

Alternatively, eq. (2) can also be written as;

$$
\mathrm{CO} 2_{\mathrm{it}}= \begin{cases}\mu_{\mathrm{i}}+\beta_{0}^{\prime} \mathrm{GDP}_{\mathrm{i}, \mathrm{t}-1}+\mathrm{u}_{\mathrm{it}}, & \text { if } \mathrm{g}\left(\mathrm{ES}_{\mathrm{i}, \mathrm{t}-1} ; \gamma, \mathrm{c}\right)=0 \\ \mu_{\mathrm{i}}+\left(\beta_{0}^{\prime}+\beta_{1}^{\prime}\right) \mathrm{GDP}_{\mathrm{i}, \mathrm{t}-1}+\mathrm{u}_{\mathrm{it}}, & \text { if } \mathrm{g}\left(\mathrm{ES}_{\mathrm{i}, \mathrm{t}-1} ; \gamma, \mathrm{c}\right)=1\end{cases}
$$

In equations (2) and (3), $\mu_{\mathrm{i}}$ is the country-specific fixed effects, $\mathrm{g}\left(\mathrm{ES} \mathrm{S}_{\mathrm{i}, \mathrm{t}-1} ; \gamma, \mathrm{c}\right)$ is the transition function, $\mathrm{ES}_{\mathrm{i}, \mathrm{t}-1}$ is the thresholding variable, $\gamma$ is the smoothness parameter, $\mathrm{c}$ is the location parameter (threshold) and $\mathrm{u}_{\mathrm{it}}$ is the error term. The variable representing economic structure (ES) consists of manufacturing, industry and services sectors shares in GDP and the data are from United Nations Conference on Trade and Development database. The variables

\footnotetext{
${ }^{1}$ The choice of the sample is mainly determined by data availability and includes Argentina, Australia, Austria, Belgium, Brazil, Bulgaria, Canada, Chile, China, Colombia, Costa Rica, Denmark, Dominican R., Ecuador, Egypt, El Salvador, Fiji, Finland, France, Germany, Greece, Guatemala, Hungary, Iceland, India, Indonesia, Ireland, Israel, Italy, Japan, Jordan, Korea R., Malaysia, Mexico, Netherlands, New Zealand, Panama, Peru, Philippines, Poland, Portugal, Romania, Singapore, South Africa, Spain, Sweden, Switzerland, Thailand, Trinidad and Tobago, Tunisia, Turkey, United Kingdom, United States, Uruguay.
} 
representing ES may be endogenous for the evolution of $\mathrm{CO}_{2}$ emissions. We tackle the potential endogeneity of ES by considering the lagged ES. By varying between 0 and 1, transition function splits the sample as low and high regimes depending on the value of thresholding variable, ES. For instance, if $\mathrm{ES} \leq \mathrm{c}$, then the transition function equals to zero and estimated parameter $\left(\beta_{0}^{\prime}\right)$ shows the impact of income on $\mathrm{CO}_{2}$ emissions in the low regime. On the other hand, if ES > c, then the transition function equals to one and estimated coefficient $\left(\beta_{0}^{\prime}+\beta_{1}^{\prime}\right)$ shows the impact of income on $\mathrm{CO}_{2}$ emissions in the high regime. Following Gonzalez et al. (2017), we use the logistic transition function as specified in (4);

$$
g\left(E S_{i, t-1} ; \gamma, c\right)=\frac{1}{1+\exp \left(-\gamma \prod_{j=1}^{m}\left(E S_{i, t-1}-c_{j}\right)\right)}
$$

where $\mathrm{c}=\left(\mathrm{c}_{1}, \mathrm{c}_{2}, \ldots, \mathrm{c}_{\mathrm{m}}\right)^{\prime}$ represents the vector of location parameters and the slope parameter $\gamma$ determines how smooth is the transition from the low to high regime. $\gamma>0$ and $\mathrm{c}_{1}<\mathrm{c}_{2}<\ldots<\mathrm{c}_{\mathrm{m}}$ are required conditions to estimate the model. Gonzalez et al. (2017) notes that the consideration of one or two threshold, i.e. $\mathrm{m}=1$ or $\mathrm{m}=2$, are sufficient in modelling the parameter changes across the regimes. For instance, the case of $m=1$ implies that coefficients change monotonically from the low regime $\left(\beta_{0}\right)$ to the high regime $\left(\beta_{0}+\beta_{1}\right)$ as the transition variable increases and the change is centered around threshold. The case of $\mathrm{m}=2$ corresponds to the quadratic logistic transition function that attains the minimum value at $\left(\mathrm{c}_{1}+\mathrm{c}_{2}\right) / 2$ and indicates a symmetric coefficient changes for the low and high values of threshold.

The initial step for PSTR estimation is to employ the homogeneity test. Under the null hypothesis of $\mathrm{H}_{0}: \gamma=0$ or $\mathrm{H}_{0}^{\prime}: \beta_{1}=0$, there are no significant thresholds and thus we obtain the linear model given by eq. (1). However, under the null hypothesis, the location parameters or thresholds are unidentified. This unidentified nuisance parameter is also valid for $\beta_{1}$ under $\mathrm{H}_{0}$ and for $\gamma$ under $\mathrm{H}_{0}^{\prime}$. To solve this problem, Gonzalez et al. (2017) proposes to replace the 
transition function $\mathrm{g}\left(\mathrm{ES}_{\mathrm{i}, \mathrm{t}-1} ; \gamma, \mathrm{c}\right)$ by first-order Taylor series expansion around $\gamma=0$ and thus, we obtain the following auxiliary regression;

$$
\mathrm{CO}_{\mathrm{it}}=\mu_{\mathrm{i}}+\beta_{0}^{\prime *} \mathrm{GDP}_{\mathrm{i}, \mathrm{t}-1}+\beta_{1}^{\prime *} \mathrm{GDP}_{\mathrm{i}, \mathrm{t}-1} \mathrm{ES}_{\mathrm{i}, \mathrm{t}-1}+\cdots+\beta_{\mathrm{m}}^{\prime *} \mathrm{GDP}_{\mathrm{i}, \mathrm{t}-1} \mathrm{ES}_{\mathrm{i}, \mathrm{t}-1}^{\mathrm{m}}+\mathrm{u}_{\mathrm{it}}^{*}
$$

Then, testing $\mathrm{H}_{0}: \gamma=0$ or $\mathrm{H}_{0}^{\prime}: \beta_{1}=0$ becomes equivalent to testing $\mathrm{H}_{0}^{*}: \beta_{1}^{*}=\cdots=\beta_{\mathrm{m}}^{*}=0$. Under the null hypothesis of $\mathrm{H}_{0}^{*}$ there are no significant thresholds and we obtain (1). Homogeneity test results are used to determine the order of logistic function based on the null hypothesis of $\mathrm{H}_{0}^{*}: \beta_{1}^{*}=\beta_{2}^{*}=\beta_{3}^{*}=0$ against the $\mathrm{H}_{01}^{*}: \beta_{3}^{*}=0, \mathrm{H}_{02}^{*}: \beta_{2}^{*}=0 \mid \beta_{3}^{*}=0$ and $\mathrm{H}_{03}^{*}: \beta_{1}^{*}=0 \mid \beta_{3}^{*}=\beta_{2}^{*}=0$. Amongst these alternative hypotheses, if the rejection of $\mathrm{H}_{02}^{*}$ is the strongest than the others, the order of logistic function is selected as $m=2$. Otherwise, the order of logistic transition function is chosen as $m=1$. The PSTR model is estimated by employing the fixed effects and nonlinear least squares (NLS) procedures. To start the NLS method, initial values are obtained by employing a two-dimensional grid search for the smoothness parameter $(\gamma)$ and threshold $(\mathrm{c})$.

As already discussed, we tackle the potential endogeneity of real GDP per capita and economic structure for the evolution of $\mathrm{CO}_{2}$ emissions by considering the lagged real GDP per capita and economic structure. Yu and Phillips (2018) considers panel threshold models with endogeneity in the regressors and thresholding variables and shows that "both the threshold point and the threshold effect parameters are ... identified without the need for instrumentation" (p.50). Therefore, our estimations may be interpreted as valid even under the potential endogeneity of real GDP per capita and the thresholding ES variables.

\subsection{Empirical Results}

The main aim of this study is to investigate whether economic structure provides an endogenous threshold for the impacts of income on $\mathrm{CO}_{2}$ emissions in 54 economies over the 1971-2017 period. To this end, we consider the share of manufacturing, industry and services 
value added in GDP as economic structure. These sectoral classifications are mainly in accord with the International Standard Industrial Classification (ISIC, Rev.3). Accordingly, the share of manufacturing value added in GDP (MVA) includes the economic activities in the physical, or chemical transformation of materials, substances or components into new products, industrial sector value added in GDP (IVA) contains the economic activities in mining and quarrying, manufacturing, electricity, gas and water supply and construction sectors and services sector value added in GDP (SVA) incorporates the value added in wholesale and retail trade, hotels and restaurants, transport, storage and communications, financial intermediation, real estate, renting and business activities, education and health sectors.

We first proceed with investigating whether the share of manufacturing sector value added in GDP (MVA) provides an endogenous threshold for the impacts of income on $\mathrm{CO}_{2}$ emissions. To this end, we consider the following specification:

$$
\mathrm{CO}_{2 \mathrm{it}}=\mu_{\mathrm{i}}+\alpha_{0} \mathrm{GDP}_{\mathrm{i}, \mathrm{t}-1}+\alpha_{1} \mathrm{GDP}_{\mathrm{i}, \mathrm{t}-1} \mathrm{~g}\left(\mathrm{MVA}_{\mathrm{i}, \mathrm{t}-1} ; \gamma, \mathrm{c}\right)+\mathrm{u}_{\mathrm{it}}
$$

Industrial sector not only includes manufacturing activities but also the economic activities in construction, mining and quarrying that incorporates substantial hazardous emissions into the environment as suggested by the bulk of the literature including Akbostanc1 et al. (2018). In this vein, to examine whether the share of industrial sector value added in GDP (IVA) constitutes an endogenous threshold in explaining the sensitivity of $\mathrm{CO}_{2}$ emissions to income, we estimate the following equation:

$$
\mathrm{CO}_{\mathrm{it}}=\mu_{\mathrm{i}}+\alpha_{0} \mathrm{GDP}_{\mathrm{i}, \mathrm{t}-1}+\alpha_{1} \mathrm{GDP}_{\mathrm{i}, \mathrm{t}-1} \mathrm{~g}\left(\mathrm{IVA}_{\mathrm{i}, \mathrm{t}-1} ; \gamma, \mathrm{c}\right)+\mathrm{u}_{\mathrm{it}}
$$

The literature suggests that the economic activities in services sector produces less $\mathrm{CO}_{2}$ emissions. Therefore, we finally proceed to analyze whether the share of services sector value added in GDP (SVA) provides an endogenous threshold for the impacts of income on $\mathrm{CO}_{2}$ emissions. To this end, we consider the following specification: 


$$
\mathrm{CO}_{\text {it }}=\mu_{\mathrm{i}}+\alpha_{0} \mathrm{GDP}_{\mathrm{i}, \mathrm{t}-1}+\alpha_{1} \mathrm{GDP}_{\mathrm{i}, \mathrm{t}-1} \mathrm{~g}\left(\mathrm{SVA}_{\mathrm{i}, \mathrm{t}-1} ; \gamma, \mathrm{c}\right)+\mathrm{u}_{\mathrm{it}}
$$

As already discussed in Section 3.1, the initial step of the PSTR estimation procedure consists of homogeneity test and results for equations (2.1), (2.2) and (2.3) are reported in Table 1. According to the heteroscedasticity and autocorrelation corrected test results $\left(\mathrm{HAC}_{X}\right.$ and $\mathrm{HAC}_{F}$ ), the null hypothesis of linearity is strongly rejected against the PSTR alternative for $\mathrm{m}=1,2,3$ when the thresholding variable is MVA in eq. (2.1), IVA in eq. (2.2) and SVA in eq. (2.3). The order of logistic transition function is selected as one for all the equations since the rejection of $H_{01}^{*}$ is the strongest than the others.

\section{[INSERT TABLE 1 AROUND HERE]}

Eq. (2.1) in Table 2 reports the estimation results of eq. (2.1) by employing the Gonzalez et al. (2017) procedure. The endogenously estimated threshold level of MVA is as around 21\%. Almost 64 percent of observations are in the low regime, whilst 36 percent of the observations are in the high regime. The results in eq. (2.1) are mainly in line with the scale effect argument by Grossman and Krueger (1991) suggesting an increase in income leads to higher $\mathrm{CO}_{2}$ emissions and thus indicate a monotonically increasing relation with income and $\mathrm{CO}_{2}$ emissions. The results also suggest that income elasticity of $\mathrm{CO}_{2}$ emissions depend on the manufacturing share of the economies. The impact of income on $\mathrm{CO}_{2}$ emissions is positive and statistically significant both in the low regime consisting of observations less than the threshold level (MVA $\leq 21.37)$ and high regime comprising observations higher than the threshold (MVA > 21.37). However, this impact is substantially much higher in economies with higher manufacturing share in income. This result is mainly in accord with Barra and Zotti (2018) and suggests that the impacts of income on pollution are substantially much higher in economies with higher manufacturing share. In the context of income-environment relation, this result 
may also suggest that manufacturing sector sharpens the upward sloping part of EKC. Figure 1.a. presents the logistic transition function across the manufacturing share of the economies.

\section{[INSERT TABLE 2 AROUND HERE]}

Eq. (2.2) in Table 2 reports the PSTR estimation results of eq. (2.2). The endogenously estimated threshold level of IVA is almost 33\%. Approximately 60 percent of the observations are in the low regime while 40 percent of the observations are in the high regime. Similar to the findings in eq. (2.1), the results in eq. (2.2) suggest the monotonically increasing relation amongst the income and $\mathrm{CO}_{2}$ emissions but the income elasticity of pollution changes across the industry share of the economies. The income elasticity of pollution is significantly positive not only in the low regime (IVA $\leq 33.23$ ) but also in the high regime (IVA $>33.23$ ). According to the results in eq. (2.2), the income elasticity of pollution is substantially much higher in countries with higher industry shares. These empirical findings in eq. (2.1) and eq. (2.2) are mainly in line with the recent literature including Akbostancı et al. (2018) and Ullah et al. (2020) and suggest that the impacts of income on environmental degradation are substantially much higher in economies with higher manufacturing and industry sector shares. Figure 1.b. reports the logistic transition function for the industrial sector share in GDP.

\section{[INSERT FIGURE 1 AROUND HERE]}

Eq. (2.3) in Table 2 reports the PSTR estimation results of eq. (2.3). The endogenously estimated threshold level of SVA is as around 62\%. Accordingly, around 56 percent of the observations are in the low regime and 44 percent are in the high regime. The estimation results indicate that the income elasticity of pollution is not invariant to the services sector shares. In the low regime containing observations with services sector share is less than $62 \%$, the income elasticity of $\mathrm{CO}_{2}$ emissions is 0.68 and it is statistically significant. In the high regime covering 
observations with services sector share is higher than the threshold, the income elasticity of emissions is 0.37 and it is almost half of the coefficient in the low regime. This result mainly suggests that the impacts of income on $\mathrm{CO}_{2}$ emissions are substantially much lower in economies with high services share or servicified economies and provides a support to the literature including Friedl and Getzner (2003), Henriques and Kander (2010), Mulder and de Groot (2012) and Marsiglio et al. (2016). Figure 1.c. shows the logistic transition function across the threshold level of services sector.

Considering that de-industrialization and servicification are the flip side of the same coin, the low regimes in eq.s (2.1) and (2.2) and high regime in eq. (2.3) mainly represent the income elasticity of pollution in servicified and de-industrialized economies whilst the high regimes in eq.s (2.1) and (2.2) and low regime in eq. (2.3) denote the sensitivity of pollution to income in economies with the high industry and manufacturing sector shares. All the estimation results reported in Table 2 mainly suggest that income elasticity of pollution is substantially much higher in economies with high manufacturing and industry shares whilst substantially much lower in economies with high services share.

\section{Conclusion and Policy Implications}

The conventional environmental Kuznets curve (EKC) investigates the relation between $\mathrm{CO}_{2}$ emissions and income that represents the aggregated measure of economic activities. EKC maintains that income leads to an increase in the pollution and after a certain threshold level of income, environmental quality improves with income. Thus, EKC posits an inverted-U shaped relation and postulates that income is both the cause and cure of environmental degradation. The bulk of the environmental economics literature maintains that the impacts of income on pollution may not vary with the economic structure (ES). This study aims to contribute to the literature by investigating whether the income elasticity of pollution is different in economies 
with high manufacturing and industry shares than the economies with high services share i.e. servicified (de-industrialized). To this end, our results based on panel smooth transition regression (PSTR) procedure by Gonzalez et al. (2017) strongly suggest that ES, indeed, provides endogenous thresholds for the impact of income on $\mathrm{CO}_{2}$ emissions.

Our results are mainly in line with the scale effect argument by Grossman and Krueger (1991) suggesting income leads to an increase in pollution. Thus, the empirical findings in this paper indicate the validity of monotonically increasing relation between income and pollution and do not provide a support to the postulated inverted-U shaped EKC. Our findings also suggest that the income elasticity of $\mathrm{CO}_{2}$ emissions may not be invariant to the endogenously estimated threshold level of ES. In this context, we find that the income elasticity of $\mathrm{CO}_{2}$ emissions is substantially much higher in economies with high manufacturing and industry shares whilst it is much lower in servicified economies. All these results, indeed, may suggest that the intensity of industry and services sector shares matter for the impacts of income on $\mathrm{CO}_{2}$ emissions. In the context of income-environment relation, our findings indicate that the high intensity of industry sector, i.e. industrialization sharpens whilst the high intensity of services sector, i.e. servicification dampens the upward sloping part of EKC.

The empirical findings of this study, in accord with the recent literature, suggest that income is an important determinant of $\mathrm{CO}_{2}$ emissions. In contrast to the conventional wisdom suggesting that service sector is "green" because it provides an improvement in environmental quality, the findings in this paper indicate that there is a positive association between income and $\mathrm{CO}_{2}$ emissions even in servicified economies, albeit this impact is substantially much lower than the economies with higher manufacturing and industry shares. In accord with the Kaldorian postulation suggesting that manufacturing is the engine of growth (Kaldor, 1966; Aiginger and Rodrik, 2020), countries can change their relative income status, for instance, from low to middle income or from middle to high income, by investing and upgrading their manufacturing 
sector. Due to the evidence that manufacturing and industrial sectors are often regarded as "dirty" sectors with higher carbon emissions, the pulling and pushing impacts for greener and healthy economy, climate change and emission reduction technologies require the consideration of also societal goals along with economic ones in preparing the industrial policy. Consistent with the findings of Ikram et al. (2019), such a policy may be expected to contain also the adoption of an environmental management system to sustain better environmental protection and higher contribution to society. All these results may be interpreted as suggesting that countries may better to design and implement a strategic and systematic industrial policy placing the manufacturing industry at the core which promotes the use of emission reduction technologies and encourages manufacturing and industrial sectors with lower carbon emissions.

\section{Declarations}

Ethics approval and consent to participate: Not Applicable.

Consent for publication: Not Applicable.

Availability of data and materials: The datasets used and/or analysed during the current study are available from the corresponding author on reasonable request.

Competing interests: The author declares that there is no competing interests. Funding: Not Applicable.

Authors' contributions: Material preparation, data collection and analysis were performed by the author.

Acknowledgements: Not Applicable.

(1)

(1)


Aiginger K, Rodrik D (2020) Rebirth of industrial policy and an agenda for the twenty-first century. J Ind Competition Trade 20(2):1-19

Akbostanci E, Türüt-Aşık S, Tunç GI (2009) The relationship between income and environment in Turkey: is there an environmental Kuznets curve?. Energy Pol 37(3):861-867

Akbostanc1 E, Tunç Gİ, Türüt-Aşık S (2018) Drivers of fuel based carbon dioxide emissions: the case of Turkey. Renew Sustain Energy Rev 81(2):2599-2608

Andreoni J, Levinson A (2001) The simple analytics of the environmental Kuznets curve. J Public Econ 80(2):269-286

Aslanidis N, Iranzo S (2009) Environment and development: is there a Kuznets curve for $\mathrm{CO}_{2}$ emissions?. Appl Econ 41(6):803-810

Baldwin R, Lopez-Gonzalez J (2015) Supply-chain trade: a portrait of global patterns and several testable hypotheses. World Econ 38(11):1682-1721

Barra C, Zotti R (2018) Investigating the non-linearity between national income and environmental pollution: international evidence of Kuznets curve. Environ Econ Policy Stud 20:179-210

Chen X, Shuai C, Wu Y, Zhang Y (2020) Analysis on the carbon emission peaks of China's industrial, building, transport, and agricultural sectors. Sci Total Environ 709:135768

Cole MA (2004) Trade, the pollution haven hypothesis and the environmental Kuznets curve: examining the linkages. Ecol Econ 48(1):71-81

Cole MA (2000) Air pollution and "dirty" industries: how and why does the composition of manufacturing output change with economic development?. Environ Resour Econ 17(1):109-123

Dinda S (2004) Environmental Kuznets curve hypothesis: a survey. Ecol Econ 49(4):431455

Dogan E, Inglesi-Lotz R (2020) The impact of economic structure to the environmental Kuznets curve (EKC) hypothesis: evidence from European countries. Environ Sci Pollut Res 27(11):12717-12724

Du H, Chen Z, Peng B, Southworth F, Ma S, Wang Y (2019) What drives $\mathrm{CO}_{2}$ emissions from the transport sector? A linkage analysis. Energy 175:195-204

Du X, Xie Z (2020) Occurrence of turning point on environmental Kuznets curve in the process of (de)industrialization. Struct Chang Econ Dyn 53:359-369

Fang Z, Huang B, Yang Z (2020) Trade openness and the environmental Kuznets curve: evidence from Chinese cities. World Econ 43(10):2622-2649

Friedl B, Getzner M (2003) Determinants of $\mathrm{CO}_{2}$ emissions in a small open economy. Ecol Econ 45(1):133-148

Gonzalez A, Teräsvirta T, Van Dijk D (2005) Panel smooth transition regression models. Quant Financ Res Centre Res Pap 165

González A, Terasvirta T, van Dijk D, Yang Y (2017) Panel smooth transition regression models. CREATES Res Pap 2017:3

Grossman G, Krueger A (1991) Environmental impacts of a North American free trade agreement. National Bureau of Economic Research, Cambridge

He J, Wang H (2012) Economic structure, development policy and environmental quality: an empirical analysis of environmental Kuznets curves with Chinese municipal data. Ecol Econ 76:49-59

He X, Yao X (2017) Foreign direct investments and the environmental Kuznets curve: new evidence from Chinese provinces. Emerg Mark Financ Trade 53(1):12-25

Henriques ST, Kander A (2010) The modest environmental relief resulting from the transition to a service economy. Ecol Econ 70(2):271-282 
Ikram M, Zhou P, Shah SAA, Liu GQ (2019) Do environmental management systems help improve corporate sustainable development? Evidence from manufacturing companies in Pakistan. J Clean Prod 226:628-641

Jayanthakumaran K, Liu Y (2012) Openness and the environmental Kuznets curve: evidence from China. Econ Model 29(3):566-576

Jiang L, He S, Zhong Z, Zhou H, He L (2019) Revisiting environmental Kuznets curve for carbon dioxide emissions: the role of trade. Struct Chang Econ Dyn 50:245-257

Kaldor N (1966) Causes of the slow rate of economic growth in the United Kingdom. Cambridge: Cambridge University Press

Kearsley A, Riddel M (2010) A further inquiry into the pollution haven hypothesis and the environmental Kuznets curve. Ecol Econ 69(4):905-919

Lin B, Li Z (2020) Is more use of electricity leading to less carbon emission growth? An analysis with a panel threshold model. Energy Pol 137:111121

Marsiglio S, Ansuategi A, Gallastegui MC (2016) The environmental Kuznets curve and the structural change hypothesis. Environ Resour Econ 63(2):265-288

Martinez-Alier J (1995) The environment as a luxury good or 'too poor to be green'. Ecol Econ 13(1):1-10

Millimet DL, List JA, Stengos T (2003) The environmental Kuznets curve: real progress or misspecified models?. Rev Econ Stat 85(4):1038-1047

Mulder P, de Groot HLF (2012) Structural change and convergence of energy intensity across OECD countries, 1970-2005. Energy Econ 34(6):1910-1921

Neve M, Hamaide B (2017) Environmental Kuznets curve with adjusted net savings as a trade-off between environment and development. Aust Econ Pap 56(1):39-58

Opoku EEO, Boachie MK (2020) The environmental impact of industrialization and foreign direct investment. Energy Pol 137:111178

Özokcu S, Özdemir Ö (2017) Economic growth, energy, and environmental Kuznets curve. Renew Sustain Energy Rev 72:639-647

Ren S, Yuan B, Ma X, Chen X (2014) International trade, FDI (foreign direct investment) and embodied $\mathrm{CO}_{2}$ emissions: a case study of Chinas industrial sectors. China Econ Rev 28: $123-134$

Richmond AK, Kaufmann RK (2006) Is there a turning point in the relationship between income and energy use and/or carbon emissions?. Ecol Econ 56(2):176-189

Savona M, Ciarli T (2019) Structural changes and sustainability. A selected review of the empirical evidence. Ecol Econ 159:244-260

Şentürk H, Omay T, Yildirim J, Köse N (2020) Environmental Kuznets curve: non-Linear panel regression analysis. Environ Model Assess 25:633-651

Shahbaz M, Haouas I, Hoang TH Van (2019) Economic growth and environmental degradation in Vietnam: is the environmental Kuznets curve a complete picture?. Emerg Mark Rev 38:197-218

Shahbaz M, Sinha A (2019) Environmental Kuznets curve for $\mathrm{CO}_{2}$ emissions: a literature survey. J Econ Stud 46(1):106-168

Stern DI (2004) The rise and fall of the environmental Kuznets curve. World Dev 32(8):1419-1439

Suri V, Chapman D (1998) Economic growth, trade and energy: implications for the environmental Kuznets curve. Ecol Econ 25(2):195-208

Torras M, Boyce JK (1998) Income, inequality, and pollution: a reassessment of the environmental Kuznets curve. Ecol Econ 25(2):147-160

Ullah S, Ozturk I, Usman A, Majeed MT, Akhtar P (2020) On the asymmetric effects of premature deindustrialization on $\mathrm{CO}_{2}$ emissions: evidence from Pakistan. Environ Sci Pollut Res 27:13692-13702 
Usman O, Iorember PT, Olanipekun IO (2019) Revisiting the environmental Kuznets curve (EKC) hypothesis in India: the effects of energy consumption and democracy. Environ Sci Pollut Res 26(13):13390-13400

Wang Y, Zhang C, Lu A, Li L, He Y, ToJo J, Zhu X (2017) A disaggregated analysis of the environmental Kuznets curve for industrial $\mathrm{CO}_{2}$ emissions in China. Appl Energy 190:172-180

$\mathrm{Xu} \mathrm{B}$, Lin B (2016) Reducing $\mathrm{CO}_{2}$ emissions in China's manufacturing industry: evidence from nonparametric additive regression models. Energy 101:161-173

Yu P, Phillips PCB (2018) Threshold regression with endogeneity. J Econom 203(1):50-68 
Figures

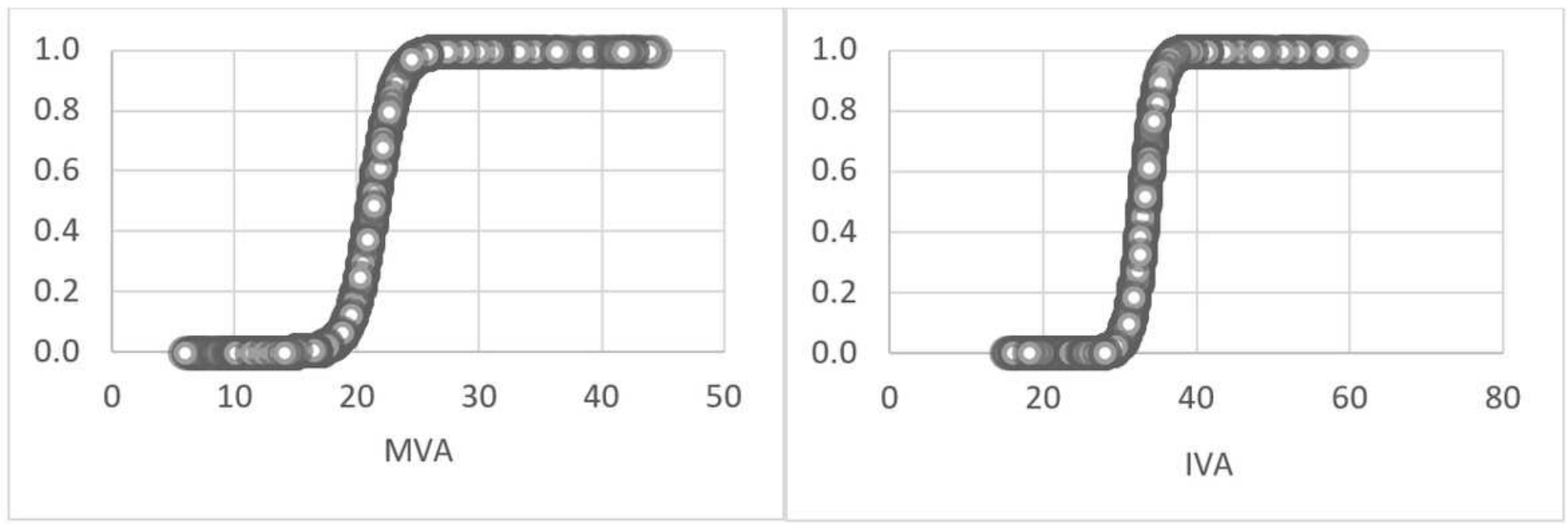

Figure 1.a.

Figure 1.b.

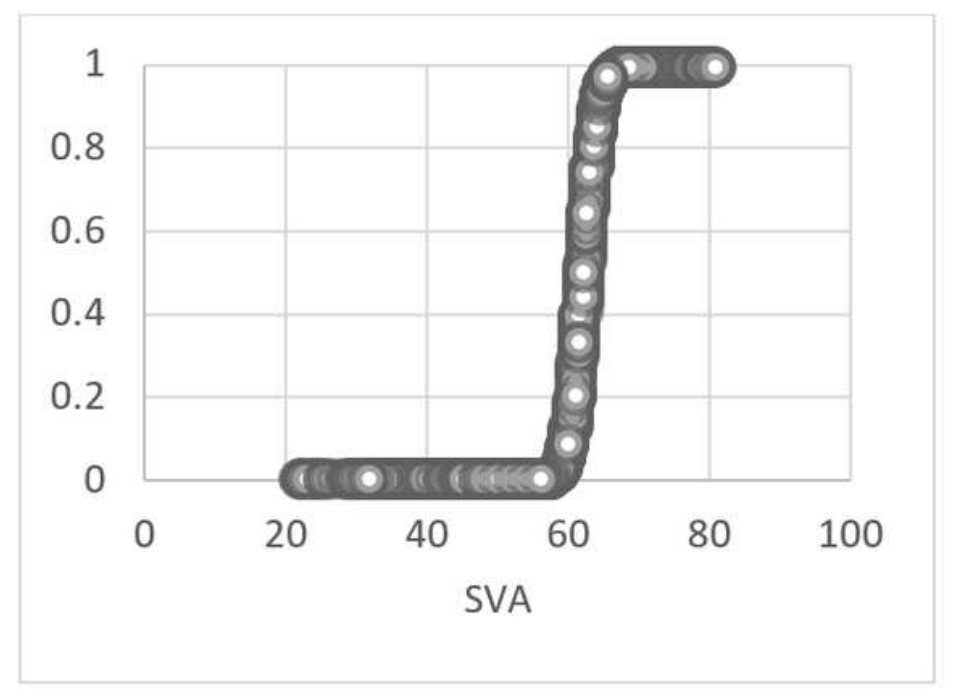

Figure 1.c

Figure 1

Transition function with respect to threshold/transition variables 